\title{
A tervezési keretrendszer innovatív megközelítése a magyarországi államháztartási szektorban $^{1}$
}

\section{An Innovative Approach to Planning Framework in Hungarian Public Finances}

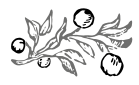

\section{Összefoglalás}

Az önkormányzatok és különböző gazdálkodási formában múködó szervezeteik jelentôs pénzforrásokat felhasználó és vagyont múködtetô szektort alkotnak, mely erôs hatást gyakorol az egész gazdaság versenyképességére. Nemzetgazdasági érdek egy olyan tervezési rendszer kialakítása, mely jól szolgálja gazdálkodásuk minôségének, a közfeladat-ellátás átláthatóságának és a feladatellátást finanszírozó közpénzek és képzôdô források mértékének minél pontosabb meghatározását. A tanulmányunkban javasolt tervezési keretrendszer proaktív stratégiai tervezésen alapszik, melyben egy komplex és konzisztens rendszert alkotnak az egyes tervezési szintek. Innovatív megközelítésben a tervezési rendszert a teljesítménymenedzsmenttel összehangoltan kell kiépíteni, melyben a programköltségvetés szemlélete, technikája jelentheti az összekötô szerepet.

Journal of Economic Literature (JEL) kódok: H72, H83

Kulcsszavak: stratégia, költségvetés-tervezés, teljesítménymenedzsment, programköltségvetés

Dr. Sisa KriszTina A., fôiskolai docens, Budapesti Gazdasági Egyetem PSZK Számvitel Intézet (sisa.krisztina@uni-bge.hu), DR. KovÁcs RóBERT, vezetố kutató, NKE ÁKK Önkormányzati Kutatóintézet (kovacsrobert@uni-nke.hu). 


\section{Summary}

Local governments and their organisations operating in different legal forms constitute a sector which uses and manages substantial financial resources. This sector has a major impact on the competitiveness of the entire economy. It is in the interest of the economy at large to develop a planning system that serves the purposes of determining, to the extent possible, the quality of the management and transparency of public service, and the volume of public and generated funds financing these services. The planning framework proposed in our study is based on proactive strategic planning, with the specific levels of planning comprising a complex and consistent system. In an innovative approach, the planning system shall be developed in accordance with performance management, with the programme budgeting approach serving as a bridge.

Journal of Economic Literature (JEL) codes: H72, H83

Keywords: strategy, budget planning, performance management, programme budgeting

\section{A TERVEZÉS ÉRTELMEZÉSE A MAI JOGSZABÁLYI KÖRNYEZETBEN}

A tervezés általános célkitúzése az Áhtv. értelmében annak biztosítása, hogy a tervezett bevételek közgazdaságilag megalapozottan, a tervezett kiadások kizárólag a közfeladatok megfelelô ellátásához szükséges mértékben és indokoltan kerüljenek jóváhagyásra. A jogszabály azt is egyértelmúen rögzíti, hogy csak olyan új közfeladat írható elô vagy vállalható, amelynek ellátásához megfelelô pénzügyi fedezet áll rendelkezésre. Ha a tervezés során a pénzügyi fedezet már nem biztosítható, intézkedni kell a közfeladat megszüntetésérôl. Az Áhtv. szerint megfogalmazott tervezési célkitúzésból levezethetố a tervezés fogalma is, amely a közszektorban elsôdlegesen az éves költségvetés elkészítésére szúkül. A helyi önkormányzatokat szabályozó Mötv. értelmében az önkormányzatoknál folyó gazdálkodás alapját az éves költségvetés teremti meg. Az önkormányzati feladatellátás forrásait és kiadásait a helyi önkormányzat egységes költségvetési rendelete elkülönítetten tartalmazza.

A hosszabb távú szemlélet is megjelenik a szabályozásban, hiszen a tervezést, a gazdálkodást és a beszámolást középtávú tervezés és ezen alapuló éves költségvetés alapján kell folytatni. A középtávú tervezés a fejezetek szerinti bontású központi költségvetés költségvetési bevételeinek és kiadásainak, a költségvetés egyenlegének és az államadósságnak a tervezésére irányul a költségvetés évét követô három év tekintetében. A középtávú tervezésnek a kormány által évente legalább két alkalommal, a tárgyévre és az azt követô négy évre vonatkozóan elkészített makrogazdasági és költségvetési előrejelzésén kell alapulnia a stabilitási törvény ${ }^{4}$ értelmében. A helyi önkormányzatoknál a képviselô-testület hosszú távú fejlesztési elképzeléseit gazdasági programban, fejlesztési tervben rögzíti, melynek elkészítéséért a helyi önkormányzat felelôs. 
A tervezésben kulcsszerepet betöltô költségvetés az Áhtv. értelmezésében egy olyan dokumentum, amely a költségvetési évben teljesülő költségvetési bevételek (bevételi előirányzatok) és költségvetési kiadások (kiadási előirányzatok) előirányzott összegét tartalmazza. A jogszabály is tervként értelmezi a költségvetést, amely a kiadások és bevételek következó évre elôirányzott, vagyis megtervezett összegeit tartalmazza. A hivatkozott tervezési fogalomrendszerben a tervezés egyszerre testesíti meg magát a tervdokumentumot és a tervalkotás folyamatát. A tervezést és a terv fogalmát ugyanakkor koncentráltan, a költségvetés terminológiával összefüggésben értelmezik jogszabályi szinten.

A költségvetésból gazdálkodók tervezési tevékenysége a költségvetés kialakítására irányul, amelynek során a hivatali dolgozók által elókészített, az alkufolyamatban minden szereplő által megvitatott és átalakult tervet (azaz költségvetést) a döntési jogkörrel felhatalmazott politikai testület elfogad (László, 1994:363). Meglátásunk szerint nem szerencsés a költségvetés-tervezés és a tervezés közé egyenlóségjelet tenni, mert a költségvetés konkrétan az évente készüló - jellemzôen éves - pénzügyi tervet takarja, ugyanakkor a tervezés ennél összetettebb, és több terület különféle idôtávot felölelô és a menedzsment különféle elvárásait kielégítô részterveinek konzisztens rendszere. A tervezés menedzsmentfelfogásához hasonlóan javasolt elkülöníteni a hosszú távú tervezést az éves (költségvetés) tervkészítés folyamatától, figyelembe véve azt az evidenciát, hogy a tervezés folyamatába természetesen mindkét tervezési terület beleértendô.

Az éves költségvetés tervezésdominanciája ugyanakkor érthetô, hiszen a költségvetés a helyi önkormányzat gazdálkodásának alapját biztosító olyan konkrét pénzalap, ami meghatározott célok finanszírozását szolgálja. Ilyen értelemben a költségvetés egy pénzügyi tervnek tekinthetô, ami jellegébôl adódóan jövoóorientált, bizonytalanságokat és kockázatokat is tartalmaz.

Közpolitikai megközelítésben a költségvetés olyan jogi dokumentum, amelyet legitim politikai testület hagy jóvá, és amely közpolitikai célok kifejezôje és érvényre juttatója (Gyôrffi-Vigvári, 2009), egyúttal a kormány programja, közpolitikai szempontból az összes állami feladat rendszerezése, pénzügyi vonatkozásban a kiadási igények és bevételi lehetôségek összehangolásának eszköze (Magyary, 1923:224, idézi Sivák-Vigvári, 2012:261).

Értelmezésünkben a tervezésre komplex rendszerként ${ }^{5}$ érdemes tekinteni, ami tartalmazza a tervek végrehajtását és a végrehajtás monitoringját is, és nem szúkül le a költségvetéstervezés folyamatára - a hagyományos és megszokott értelmezéssel ellentétben -, hanem magában foglalja a stratégiai, taktikai és egyéb rövid távú tervezési feladatokat is.

\section{A TERVEZÉS JELENTÓSÉGE A KÖZSZEKTORBAN}

Egy akkurátus és kellôen megalapozott tervezéssel a jövố válik a cselekvések, döntések mozgatórugójává. A tervezés tehát egy jövőorientált tevékenység, amely orientáció jelentôsége vitathatatlan a közszektorban. A tervezés közszektorbeli kiemelt jelentôsége a következô okokra vezethetô vissza: 
- A költségvetési szervek az állampolgárok különféle jogcímeken megvalósuló befizetéseiból látják el a közfeladatokat, illetve elégítik ki a társadalmi közös szükségleteket. Az adófizetô állampolgárok - joggal - szeretnék tudni, hogy a befizetéseikért cserébe milyen ellenszolgáltatás jár (társadalmi kontroll). Erre pedig akkor tud minél pontosabban válaszolni az „állam”, ha pontos költségvetés (terv) készül az ellátandó közfeladatokról (kiadási szükségletekrôl) és azok pénzügyi fedezeteirôl (finanszírozási forrásairól). Az államnak elszámoltathatónak kell lennie. Ennek alapfeltételét képezi a közszolgáltatások (output és outcome) mérhetôsége és a költségvetés-készítés gyakorlati megvalósítása a tervezés során, a megfelelő tervezési módszer alkalmazásán keresztül.

- A tervezés jövooorientált jellegének szükségessége, szemben a piaci szektorral, a közösségi jellegéból is adódik. A piaci szektorban a múködés irányát a tulajdonos vagy annak képviselője határozza meg, hiszen a tulajdonos viseli a kockázatokat. Ezzel szemben a közszektorban ilyen kockázatviselő nincs, hacsak nem maga a teljes képviselt közösség. A politikai vagy a köztisztviselői felelôsség korlátozott, nem terjedhet ki a teljes vagyonvesztésre, mint a magántulajdonos esetében. Éppen ezért kell a célokat és az eszközök használatát előre, kiszámítható és számon kérhetô módon tervezni.

- Az állam és különbözô apparátusai lassan reagálnak a gazdasági környezet, a piaci keresleti-kínálati viszonyok impulzusaira, ezért a közfeladat-ellátást és finanszírozási rendszert minél pontosabban, előrelátóan, a bizonytalanságok, kockázatok szintjének minimalizálásával kell végiggondolni, azaz megtervezni.

A tervezés szükségességét alátámasztó további indoklások „szektorsemleges”-ek, mint például a tervezéssel a jövô motiválja a vezetôi döntéseket, a múködésben rejlô bizonytalanságok, kockázatok csökkenthetôk egy pontos, jól átgondolt és formalizált tervezéssel, a tervezés kijelöli egy szervezet számára a fejlődési pályát, amelyen végighaladva eredményesebben (célorientáltan), sikeresebben tud múködni.

A modern piacgazdaságban múködó közszektor tervezésének jellemzô vonásai Faragó alapján az alábbi jellemzókkel rendelkeznek:

- „többszintú és sokszereplős (a rendszer nem csak a gazdaság alapellentéteiból áll);

- kétirányú (egyszerre top-down és bottom-up);

- elfogadja az állami (kívülrôl, felülről) beavatkozás szükségességét (a nemzet távlati érdekeit érvényesíti);

- értékpluralista;

- törekszik megfelelni a társadalmi tudás szintjének (tudományos és racionális), ugyanakkor korlátozza a rendelkezésre álló információ tömege és jellege;

- duális: részben segíti (generálja), részben korlátozza a magánszférát;

- politikailag meghatározott" (Faragó, 1997).

A tervezés teremt kapcsolatot az önkormányzat és környezete között. A tervezés segítségével kell felkészülni a környezet várható változásaira, kihívásaira. A környezeti elemek közül kiemelt szerepet játszik a jogszabályi környezet mint „magyarázó változó”, mert ez befolyásolja, magyarázza közvetlenül a tervezési rendszer mint „függő változó” múködésének alapvetô feltételrendszerét. 


\section{A stratégiai SZEMLÉlet MEgJELENÉSE}

\section{A JELENLEGI TERVEZÉSI RENDSZERBEN}

A jelenlegi jogszabályi környezetben hosszú távú tervezési feladatok a rendezési eszközök, a településfejlesztési koncepció és a rendezési tervek, valamint a választási ciklusokhoz igazodó gazdasági program. Egyes ágazati törvények meghatározhatnak hosszú távú programot, tervkészítési kötelezettséget is, ilyen például egy környezetvédelmi program, vidékfejlesztési, turisztikai koncepció stb. A Mötv. előírása alapján az önkormányzatoknak meg kell határozni gazdasági programjukat. A választást követôen a megalakult önkormányzati vezetés az eloozố kormányzati ciklus eredményei, tapasztalatai és saját választási célkitúzései, jövőre irányuló elképzelései alapján hosszú távú fejlesztési elképzeléseit gazdasági programban, fejlesztési tervben rögzíti. A gazdasági program által felölelt időhorizont a Mötv. értelmében a képviselô-testület megbízatásának idôtartamára (ez jelenleg Magyarországon öt év) szól, de ennél hosszabb idôszakot is átfoghat. Ilyen értelemben a gazdasági program alkalmas lehet betölteni egy átfogó hosszú távú terv szerepét, amennyiben megjelennek benne a stratégiai fontosságú múködési területek fố célkitûzései, eszközei, elérésük módja és a stratégiaiterv-elemek. Azonban sem az Mötv., sem az Áhtv. a gazdasági program szerkezetére, tartalmára, formájára, érvényességére vonatkozóan nem tartalmaz kötelezó erejú elooírást, ebból következóen az önkormányzat maga határozza meg hosszú távú célkitûzéseit és a megvalósítás feltételeit, eszközrendszerét. A gazdasági programok tartalmára vonatkozóan nincs részletes jogszabályi előírás, ehelyett egy átfogó megállapítást fogalmaz meg a jogszabály.

Ezt követôen a gazdasági programnak mint hosszú távú, átfogó tervnek a funkciója az évente készülő költségvetési koncepció és éves költségvetés megalapozása.

A hosszú távú tervezés másik katalizátora az EU támogatáspolitikája, amely megköveteli a pályázó intézmény hosszú távú tervkészítését a jellemzôen beruházási-fejlesztési projektek finanszírozási forrásainak megszerzéséért cserében. Az EU-s források megszerzése érdekében készülố tervek az EU-s támogatási lehetôség kiaknázására, illetve az egyedi projektek megvalósítására irányulnak, azonban az egyes fejlesztések nem egymással öszszehangoltan valósulnak meg. Bár az önkormányzatok rendelkeznek különbözô stratégiai dokumentumokkal, azok minden fejlesztésre kiható jellege nem jellemzô. A stratégiai dokumentumok sok esetben inkább projektszemléletúek, mint koncepcionális, stratégiai szinten megfogalmazott fejlesztési irányok (Döbröntei, 2008).

Meglátásunk szerint a gazdasági program alkalmas keretül szolgálhat az átfogó stratégiai tervezésre. A gazdasági program akkor töltheti be egy átfogó stratégiai terv funkcióját, ha az abban kijelölt célok, feladatok, programok beépülnek az éves költségvetésekbe, és az önkormányzat a programban kijelölt „pályán” tud haladni a célelérés felé.

\section{EGY JAVASOLT TERVEZÉSI KERETRENDSZER FELÉPÍTÉSE}

A tanulmányunkban javasolt tervezési rendszer keretjellegú, komplex és flexibilis. A keretjelleggel arra utalunk, hogy a tervezési rendszer, tevékenység megvalósítására rendelkezésre álló és ismert tervezési alapelvek, szabályok és módszerek teremtik 
meg a konkrét intézménynél kialakítandó tervezési rendszer „határait”, adják meg annak keretét. Ez a keret egy ajánlás, amelyból kiindulva kell/lehet kialakítani a konkrét intézmény egyedi, testreszabott tervezési rendszerét. Egy „jó” tervezési rendszer ugyanakkor komplex, vagyis egy jól átgondolt, számszakilag is megalapozott és kockázatelemzéssel alátámasztott stratégiai tervezéssel kezdódik, és abból kiindulva tartalmazza a tervezés taktikai (középtávú) és operatív (éves költségvetés) terveit is. A flexibilitási feltétel alatt a változásokra történô azonnali beavatkozás képességét értjük, ami a gyakorlatban a stratégiai tervek (koncepciók) újragondolását, új „irányok” kijelölését, a stratégia szükség szerinti módosítását jelenti, ami az éves költségvetés szintjén az előirányzatok módosításában, szükségszerú és indokolt átcsoportosításában realizálódik.

Az önkormányzati modern tervezés értelmezése annyiban közelít a tervezés üzleti felfogásához, hogy a tervezési folyamat részeként említi a környezet és a szervezet belsố adottságainak, képességeinek elemzését, továbbá felhívja a figyelmet a tervezésben részt vevôk közötti kooperációs folyamatra is, melynek végeredményeként az elkészült terv a különféle érdekeltek (stakeholder) eltérô igényeit egyaránt tükrözô dokumentum szerepét kell hogy betöltse.

A modern önkormányzati tervezés teljesítmény-és eredménycentrikus. A teljesítmény- és eredményközpontú tervezési rendszer fóbb elemei: a stratégiai tervezés, taktikai tervezés, rövid távú (operatív) tervezés (éves átfogó és részletes operatív terv) és a teljesítménymenedzsment. A tervezésnél a programköltségvetés módszerét javasoljuk keretül (1. ábra).

\section{1. ábra: Önkormányzati tervezési szintek és tervdokumentumok javasolt rendszere}

\begin{tabular}{|c|c|c|}
\hline Tervezési szint & Időtáv & Tervdokumentumok \\
\hline Középtávú (taktikai) & $\begin{array}{c}\text { minimum két } \\
\text { kormányzati } \\
\text { ciklus } \\
\text { egy kormányzati } \\
\text { ciklus } \\
\text { maximum egy év }\end{array}$ & $\begin{array}{c}\text { Átfogó gazdasági program } \\
\text { Településfejlesztési koncepció és városfejlesztési } \\
\text { stratégia } \\
\text { Programstratégiák } \\
\text { Erôforrás-stratégiák, EU-pályázatok } \\
\text { Kormányzati funkciók (ágazatok) szerinti } \\
\text { cselekvési programok (programozás) } \\
\text { Többéves költségvetés } \\
\text { Középtávú erôforrástervek } \\
\text { Éves átfogó operatív terv } \\
\text { Részletes operatív terv }\end{array}$ \\
\hline
\end{tabular}

Forrás: Sisa, 2014:208

A tervezési rendszer hajtómotorja csak egy proaktív, konkrét és a fóbb stratégiai területekre koncentráló stratégiai terv lehet, amely nem kényszerból készül. A jelenlegi hosszú távú tervkészítés leginkább a jogszabályoknak megfelelés érdekében és az aktuális támogatási lehetôségek által vezérelve zajlik, és nem a helyi közösség igényei (szükségletei) alapján és érdekében készül. A kényszerúség abban is meglátszik, hogy az 
elkészült hosszú távú tervek végrehajtását nem követik nyomon, és nem kérik számon a végrehajtásért feleloos vezetôktől. Egy ilyen felfogásban elkészített hosszú távú terv nem a várható környezeti változásokra felkészülő, a lehetôségeket keresô aktív terv, hanem a változásokhoz passzívan alkalmazkodó, a jelenben érvényes adottságokra és körülményekre építô terv. A hosszú távú tervezéssel az erôsségek feltárásán és kihasználásán keresztül a helyi lehetôségek keresésére és kiaknázására kell törekedni. A gazdasági program alkalmas betölteni az átfogó stratégiai tervdokumentum szerepét. A közszektorra javasolt stratégiai tervezés, illetve stratégiai menedzsment kialakításának leginkább nemzetközi tapasztalatai és ajánlásai állnak rendelkezésre (pl. Poister, 2010; Johnsen, 2015; Wauders, 2017), amelyek kiváló kiindulási és tanulási alapot képesek teremteni a hazai megvalósítási folyamatban.

Véleményünk szerint az önkormányzatok tervezési tevékenysége - hasonlóan az üzleti szektorhoz - nem korlátozódhat kizárólag a tervek elkészítésének folyamatára, hiszen a tervezés sikerességének egyik fokméróje a tervek eredményes megvalósítása, a cselekvést, mindennapi feladatellátást és vezetối döntéshozatalt támogató ereje, ezért foglalkozni kell a tervek végrehajtásának elemzésével, az erre épülő beszámolási folyamatokon keresztül, a tervezés és a tervekben kitûzött célok megvalósításának hatékonyságát és eredményességét mérố mutatószámrendszer kidolgozásával együtt. ${ }^{6}$

Az elemzések a tervteljesítésekre vonatkoznak, ezért az elemzés és beszámolás tevékenysége nem szakadhat el önálló tevékenységként a tervezéstôl, ennek értelmében a tervezési folyamat részeként értelmezzük az elemzés-beszámolás folyamatait is. ${ }^{7}$

\section{EGY INNOVATÍV MEGKÖZELÍTÉS: A TELJESÍTMÉNYMENEDZSMENT ÉS A PROGRAMKÖLTSÉGVETÉS}

Az önkormányzati tervezés-gazdálkodás megújítását túztük ki célul a szakszerúség, az átláthatóság, a hatékonyság és korszerú pénzügyi menedzsment és szervezeti technikák mentén. A javasolt rendszer középpontjába az úgynevezett programköltségvetést és a teljesítménymenedzsment egy meghatározott formáját helyeztük. Az elóbbi a tágabb keretet jelenti, az utóbbi konkrét technikák egy csoportjának összefoglaló neve. Összességében források, erôforrások és erôfeszítések koncentrációját, a célok teljesülésének és eredményességének kontrollját, mérését teszik lehetôvé. A javasolt megoldás keretében az önkormányzat a stratégiai programokhoz hasonlatosan építi fel a múködését, ennek információs bázisát az eredményszemléletú számvitel rendszerébôl, illetve az azt kiegészítô saját rendszeréből kapja, és ezen, illetve kiegészítô információkra alapozva folyamatosan figyelemmel kíséri a program vagy terv megvalósítását, az eredményeket és az eredményességet. Demokratikus feltételek mellett a helyi politika érdeke az eredmények láthatóvá tétele, hiszen ezzel tudja leghatékonyabban szemléltetni a politikai ciklus során elért eredményeit.

A teljesítménymenedzsment közvetlen célja az irányítás hatékonyságának növelése. Ki kell ugyanakkor emelni, hogy a hatékonyság nem az olcsóságot, a hatékony megoldás nem a legolcsóbb megoldást jelenti. Az a leghatékonyabb megoldás, amelynek esetében a költségek, a ráfordított források és az elért eredmények, a szakmai teljesít- 
mény optimális egyensúlyban állnak. A rossz, nem múködő, de kevés forrást igénylő szolgáltatás nem hatékonyabb a célokat teljesítô, de drágább szolgáltatásnál. A teljesítménymenedzsment a kiválasztott eszköz múködése hatékonyságának mérését jelenti, vagyis azt, hogy mennyiben ténylegesen az eredeti cél megvalósulását segíti, milyen mértékben, ütemben halad megvalósulása, illetve milyenek a fajlagos (egy lakosra, ellátottra, intézményre stb.) jutó költségek. Ezek az eszközök lehetôvé teszik a menet közbeni beavatkozást, szélsôséges esetben az alkalmazott eszközök felülvizsgálatát.

Léteznek már a mai önkormányzati szabályozási és pénzügyi rendszerben olyan eszközök, amelyek hatékonyságot igyekeznek erôsíteni. Hatásosságuk ugyanakkor ellentmondásos. Az általunk javasolt megoldások belsô, nem külsố célokat követnek, hatásos alkalmazás esetén a megtakarítások, eredmények az önkormányzatoknál jelentkeznek. ${ }^{8}$ Végsố soron tapasztalati ténynek tekinthetô, hogy a kívülrôl erốltetett hatékonysági erőfeszitések ritkán eredményesek, gyakran nem szándékolt, ellentétes hatású cselekvésekhez vezetnek. Ennek okai részben a helyi viszonyok összetettségében, kívülrôl való átláthatatlanságában van, részben pedig a bonyolult helyi érdekekben, érdekeltségekben találhatóak. Az önkormányzatok központi finanszírozásának célzottá és költségarányossá tétele tehát az eredeti célokkal ellentétes módon a költségek növekedéséhez, burkolt költségek megjelenéséhez vezethet. Nehezen elképzelhetô olyan költségszámítás, bár vannak, voltak rá kísérletek, amely minden település minden intézménye esetében reális értéket képes becsülni. Nem beszélve arról a problémáról, hogy a hazai feltételek mellett az így eredményül kapott költségszint várhatóan lényegesen magasabb, mint amit a központi költségvetés fedezni tudna. ${ }^{9}$ Ugyanakkor a központi finanszírozás tervezése esetében érdemes azt a szempontot is figyelembe venni, hogy az átlagos költségektôl való eltérést nemcsak az elaprózott szolgáltatórendszer eredményezhet, hanem speciális, például településmorfológiai problémák vagy minôségi szolgáltatások, például kiscsoportos zenei képzés. Éppen ezért általában azok a finanszírozási technikák múködnek jobban, amelyek minél egyszerúbben (kevés paraméter figyelembevételével) próbálják a forrásokat biztosítani, de bezárják a kiskapukat, „kemény költségvetési korlátot” képeznek. A sajátosságokat pedig meghatározott prioritások mentén, egyedi eszközökkel, de normatív alapon kezelik (Kovács, 2007; Kovács-Sükösd, 2014; Gazsó-Kovács, 2014).

A mai önkormányzati szabályozási és gyakorlati közegben ezek a külsố és belsố ösztönzók párhuzamosan múködnek. Az arány a szabadon felhasználható és a helyi források költségvetési aránya szerint módosul, hiszen a hatékonyságot a megtakarítások helyi felhasználásának lehetôségével lehet a legjobban ösztönözni. Ez nagyobb szabadságot biztosít a helyi prioritásoknak a központiakkal szemben. A programköltségvetés több tekintetben rokonságot mutat a hazai gyakorlatban feladatfinanszírozásként meghonosított megoldásokkal. A különbség tehát az, hogy az elôbbi esetében a kormányzat vagy az önkormányzat önmagára alkalmazza, vagyis saját feladatainak múködtetését és finanszírozását rendezi olyan keretek közé, ahol az intézmények és a meglévő kötöttségek, „infrastruktúrák” helyett a problémák megoldása, a „feladat” kerül előtérbe. Alapesetben az ellátási alternatívák keresésével az önkormányzat adott minôség mellett a legolcsóbb megoldást keresheti meg. A mai szabályozási keret 
ugyanakkor egyre jobban diszpreferálja az alternatív ellátási formákat, előnyben részesíti a minél közvetlenebb közösségi, önkormányzati ellátási formákat. Eredendôen a 3-6 éves kisgyerekek ellátását az önkormányzat megoldhatná a saját óvodával, de akár a szomszédos településsel vagy magán-, egyházi, esetleg alapítványi intézményekkel kötött szerzôdéssel. Valójában a hazai konkrét feltételek mellett a feladatfinanszírozás a kormányzat eszköze az önkormányzat kiadásainak keretek közé szorítására. Azt gondoljuk, hogy több tekintetben rossz úton jár, amikor bürokratikus eszközökkel igyekszik keretek közé szorítani az önkormányzati transzfereket. Ez ugyanakkor e tekintetben másodlagos; a külsô vagy belsô hatékonysági kényszer a kérdés.

A hatékony, a célracionális múködés elérésének egyik érdekesebb, belülrôl vezérelt eszköze lehet az önkormányzati menedzsment programelvú átszervezése a teljes vertikumában, mind a múködésének, a fejlesztéseinek a tekintetében. Egy önkormányzat ma, a hazai viszonyok között, nagyszámú programot múködtet párhuzamosan. Ezeket minden külsố kényszer nélkül, de maguk alkotják meg (gazdasági program, szakprogramok, fejlesztési programok). Az Mötv. elôírása, tehát törvényi kötelezettség alapján alkotják meg az önkormányzatok a választásokat követôen az úgynevezett ciklus- vagy gazdasági programjukat. Mint egyfajta külsô kényszerként megjelenô feladat, ahogy más hazai intézmények esetében is, gyakran formálisan, kiüresedetten múködik ez az intézmény is. Kevés az az önkormányzat, amely azt a lehetôséget látja benne, hogy megtervezze saját négy-öt éves múködését, és a választott és kötelezô feladataikat öszszehangolja, megtervezze. A gazdasági program készítésének kötelezettsége az önkormányzati törvény szintjén szabályozott, és a képviselő-testületek feladataként határozzák meg. A gazdasági program akkor tölti be tervezési-menedzsmenteszköz funkcióját, ha az önkormányzat valós tartalommal tölti meg, és programozási keretet ad neki (célokhoz eszközök, források stb. hozzárendelése), amely ténylegesen megvalósítható, reális céljait harmonizálja, pénzügyi-közgazdasági tervezési eszközökkel, tényleges költségek, források megjelölésével, erőforrások, határidôk hozzárendelésével egy követhetố itinert alakít ki.

Jelenleg az önkormányzatok törvényes kötelezettségei, pályázati ösztönzôi között több program elkészítése szerepel. Ilyen programok például az integrált településfejlesztési terv (ITS), társadalmi integrációs terv stb. Kiemelt helyet foglal e jövóképek között az integrált településfejlesztési terv, amely nevében is hordozza átfogó jellegét, és valóban egyre több részstratégia épül bele. Az ITS-sek azért képesek több párhuzamos részprogram integrálására, mert gyökerüket és végsố céljukat tekintve is hasonlóan, az uniós források elnyeréséhez kapcsolódnak. Láthattuk, hogy a gazdasági program gyökere és célja némileg eltér: hazai törvényekból fakad, és a politikai ciklus teendőinek áttekintése, összehangolása a célja, legyen az fejlesztés vagy múködtetés. További különbség a két tervezési dokumentum között, hogy a belsô ügyként kezelt gazdasági program esetében előfordul, hogy a polgármesteri hivatal dolgozói állítják össze, mint egyfajta feladatlistát, míg az ITS-sel professzionális módon, külsố szükségleteknek kívánnak megfelelni, amelytől jelentős (fejlesztési) forrást várnak, így többnyire külsố szakértô, tanácsadó készíti. Az ITS-ek ráadásul igazodnak a hazai és uniós fejlesztési célrendszerbe. Míg tehát a gazdasági program, elvi szinten, a belsố 
szükségleteket szolgálja, az utóbbi a külsô megfelelést, a hétéves uniós fejlesztési ciklus potenciálisan felmerülő összes fejlesztési, pályázati lehetőségének előzetes beszámítását. Az ITS-t annak ellenére, hogy komoly ráhatással van rá a helyi vezetés, megvitatja és elfogadja a képviselő-testület, és sokszor megalapozottabb és szélesebb helyi társadalmiigény-felmérés van mögötte, csak korlátozottan tükrözi a belsố szükségleteket. A két dokumentumban megfogalmazott célok jelentôsen eltérhetnek. Egyelőre hivatalos fórumokon nem foglalkoznak a gazdasági program és az ITS-ek integrációjával, hiszen a hazai viszonyok között a fejlesztések és a múködtetés mintha két teljesen külön világ lenne. A Magyar Urbanisztikai Társaság és a Helyi Obszervatórium a TÖOSZszal is együttmúködve tettek korábban kísérletet a két dokumentum integrációjára, de ezek a kezdeményezések elhaltak: az a menedzsmentmódszer, amely e tanulmány tárgyát is képezi, ráadásul a fenti középtávú terveket és a rövid távú, éves költségvetési tervezést is össze kívánja hangolni, egyetlen, közös tervezési keretrendszerbe integrálva mindegyiket.

A legnagyobb önkormányzatok sem mindig ismerik fel az erőforrásokkal való racionális gazdálkodás, a közép- és hosszú távú tervezés, a jövô tervezésének a jelentôségét, pedig az esetükben jelentôs hatékonyságnövekedés érhetô el, amely ezekben a városokban viszonylag gyorsan érezhetô eredményeket hozhat. A tényeken, elôrejelzéseken alapuló, szakszerú tervezéssel szembeni ellenállás okai minden bizonnyal mélyen, a feltételek folyamatos változásában, kiszámíthatatlanságában, a kiszolgáltatottságában és a rendszerváltás elôtti tervezés kiüresedett, értelmetlen, ráerôszakolt voltából következik. Nehéz egy átlagos helyi vezetôt arról meggyôzni, hogy a tervezésen alapuló cselekvés, a politikai program ilyenformán történô megvalósítása tényleges politikai hozadékkal járhat, mert a megalapozott terv segít felkészülni a különbözô várható jövô-forgatókönyvekre, koncentrálja a szabad kapacitásait az általa elérni kívánt célokra, illetve adott esetben fel is szabadít kapacitásokat ezekre a célokra. Személyes beszélgetések alapján úgy túnik, nem egyszerúen a feltételrendszer hiánya (mozgástér, konkrét intézkedések hatása) okozza, hogy kevés helyi vezetô képes kilépni az egyik napról a másikra élés csapdájából, sokkal inkább egy évek óta növekvố apátia és párhuzamosan a kiválasztódás, a tettre készebb emberek elfordulása. Ahhoz, hogy egy helyi vezetô proaktívan lépjen fel, elkezdje keresni a lehetôségeket a helyi viszonyok jobbá tételére, valamiféle optimizmus kell, a siker legalább minimális reménye. Stabilitás helyett egy-másfél évtizede a helyi viszonyokat a fokozatosan nehezülő pénzügyi terhek, áthárított központi költségvetési konszolidáció, zsugorodás és bizonytalan jövố jellemzik. Egyre kevesebben látják, hogy mire lehet építkezni. Ezzel párhuzamosan fokozatosan szúkültek a szabadon felhasználható helyi források, egyre inkább a központi célokra célzottan szabott pénzügyi eszközöket biztosított a mindenkori kormány. A fejlesztési célokat sem a helyi viszonyokra optimalizáltan pályáztatják, hanem uniós vagy kormányzati célok, esetleg szakmai divatok, lobbitevékenység nyomán. A helyi vezetô, ha pályázik, és a helyi érdekeknek megfelelően jár el, akkor szabálytalanságot követ el; ha követi a szabályokat, akkor az esetlegesen felesleges létesítmény múködésébe rokkanhat bele az önkormányzat; ha nem lép, akkor viszont nem fejlődik a település. A csábító, látszólag ingyenes pályázati forrá- 
soknak nehéz ellenállni. Szúkülő mozgástér mellett is többféle lehetôség áll rendelkezésre a legtöbb települési vezetô számára.

A kulcs ugyanakkor a felelôs stratégiai gondolkodás, amely számszerúsíti a különbözô megoldások pénzügyi és más következményeit, világosan megmutatja, hogy adott feltételek mellett melyek a reális alternatívák. Fontos annak tudatosítása, hogy a látszat ellenére a költségek végsố viselője a helyi önkormányzat és a helyi lakosság, vállalkozások. Az önkormányzati rendszer olyan irányba mozog, hogy úgy túnhet, a felelôsségek (helyi döntési és teherviselési) az önkormányzaton kívülre kerülnek. Ha a helyi szereplôk nem érzik a felesleges, oda nem illő létesítmények, célok következményeit, hanem azt fáradságos elôszobázás izzadságos gyümölcseként élik meg, akkor nem fognak pénzügyi-gazdálkodási értelemben racionálisan viselkedni. Ha a sikerességüket nem elsôdlegesen helyben, hanem központi listákon mérik, akkor annak próbálnak megfelelni.

„Nem feltétlenül az az önkormányzat a legsikeresebb, amelynek a múködése valódi, megalapozott programot követ. A »siker « leggyakrabban a jó kiinduló feltételektôl, kimagasló (vezetôii) képességektől vagy végtelen energiával rendelkezô vezetôktől, lelkes közremúködôktôl függ. A programon alapuló múködés, a pénzügyi értelemben megtervezett költségvetés olcsóbb, minôségibb munkát eredményez. A lakosság, civilek, vállalkozók bevonása a stratégiai döntéshozatalba megalapozottabb, tartós eredményeket hozhat, ciklusokon átívelô fejlesztéseket tesz lehetôvé” (Kovács, 2016:348). A hosszú, közép- és rövid távú tervezés összehangolt rendszerébe ágyazott stratégiai tervezés, párosítva a teljesítményelvú pénzügyi és általános önkormányzati menedzsmenttel, látványos, gyors sikereket ígérô megoldásokkal szemben programozott módon, magas minôségben, a tervezett határidôre biztosítja az eredményt. Egy erôs jövôkép kialakítása, követhetô célok meghatározása és számszerúsítése (költségek, erôforrások, határidôk), az önkormányzat tényleges helyzetének felmérése, források felszabadítása alternatív megoldások felkutatásával, a célokhoz rendelt kiadások és források költségeinek felmérése, a lehetôségek összevetése új perspektívákat nyithat. Amennyiben a tervezés során a lehetô legszélesebb konszenzus, valódi együttgondolkodás nyomán kialakuló programot, folyamatos monitoring és visszacsatolás mellett valósít meg az önkormányzat, nagy biztonsággal mondható meg, hogy céljai elérésében eredményes, megítélésében sikeres lesz. „A programköltségvetés a stratégiai tervezéshez hasonló módon a célok meghatározásán és e célokhoz eszközök hozzárendelésén alapszik. A programszerú múködés több tekintetben forradalmasítja a hagyományos közszektorbeli tervezést" (Kovács, 2016:353). A költségvetés, Phil Rosenberg szavaival, már nem egyszerúen egy számviteli törvény szerinti megfelelés, hanem egy politikai dokumentum (Rosenberg, 1999; Hegedüs et al., 1999). Ehhez tegyük hozzá, hogy egyúttal egy rövid távú terv is, amely része egy középtávú tervnek, programnak stb. A programköltségvetés fogalomrendszerébe ágyazva a gazdasági program, megfelelô kidolgozottság mellett, tekinthetố a ciklus politikai-gazdasági tervének, amelynek konkretizálása éves szinten a költségvetési terv. A gazdasági program a politikai szándékok mellett már reális célokat kell hogy tartalmazzon, de az éves költségvetés is ezeket a szándékokat kell hogy tovább konkretizálja, hiszen ugyanaz a vezetés terjeszti elő, ugyanazon irányítás mellett, ugyanannak az infrastruktúrának, kapacitásoknak, erôforrásoknak a felhasználásával fog megvalósulni. 
A ciklusok között ugyanakkor a ciklusokon átíveló akciók, beruházások mellett is tiszta helyzetet kell teremteni. Az új gazdasági programnak a tiszta helyzethez a legalapvetőbb építőelemekból, azok szükségességének indokoltságából kell felépülnie.

2. ábra: A programköltségvetés javasolt modellje

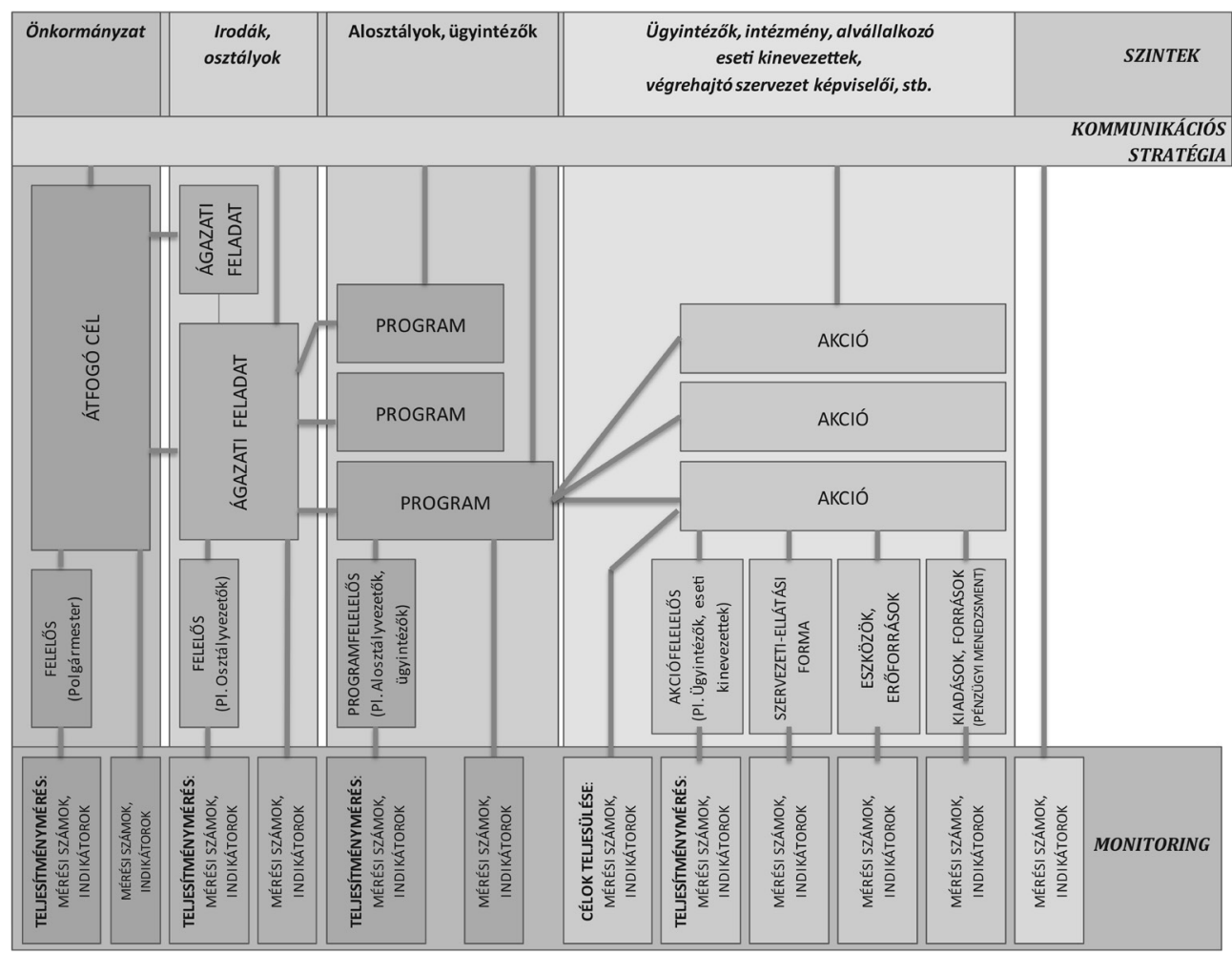

Forrás: Kovács, 2015

A programköltségvetés, abban a sajátos felfogásban, a fentiekben vázolt módon, ahogy a jelen tanulmányban bemutattuk, egyetlen, közös stratégiai tervezési keretbe foglalja a költségvetési tervezést, amelyben helye van a gazdasági programnak mint középtávú tervnek és az éves költségvetésnek mint rövid távú tervnek. A tervezésnek és a költségvetésnek ez az értelmezése megfordítja a „ki van kiért” kérdését, kilép a legszúkebb értelemben vett számviteli keretek közül. ${ }^{10}$ Elôtérbe kerül a politikai érdek, szándék, és a hagyományos költségvetés-készítési eljárás alárendelődik e politikai szándéknak. Nem a szakmaiság, nem a törvényi kötelezettség rendelôdik alá a politikai szándéknak, hanem azok a tartalmi elemek, célok válnak nyíltan politikavezéreltté, amelyek amúgy is azok. A politikai szándék a választott képviseló akarata, a választási program konkretizálása, reális céljainak kiemelése. Amennyiben a két tervezési forma nem egyeztethetô össze, úgy a fenti módon kialakított költségvetési terv mellett szükséges egy, a számviteli törvénynek megfeleló második költségvetés is. Ennek alap- 
ja azonban a „politikai-stratégiai dokumentum” kell hogy legyen. A hazai feltételek mellett, a legalább részben eredményszemléletú vagy elhatárolásalapú számvitelnek a közszférában történt 2014-es bevezetésével ez már nem jelent ekkora gondot, a két szemlélet összehangolható. Ennek eszköze (Donat-Milos, 2008) a COFOG (Eurostat, 2007) kódrendszerének helyi szintekkel való kiegészítése. Az összehangolt kódrendszer a forrása nem csupán az új szemléletú költségvetési tervezésnek, de a teljes teljesítményelvú menedzsment információs rendszerének is, ${ }^{11}$ beleértve ez utóbbiba a program megvalósításának folyamatos nyomon követését stb.

A fenti tervezési rendszer bevezetése, nemzetközi tapasztalatok nyomán, szükségessé teszi a programmenedzsment rendszerének egyértelmúvé tételét. Ennek érdekében félreérthetetlen fogalmi rendszert kell alkalmazni, amelyet összhangba kell hozni a szervezeten belüli felelôsségekkel. Ilyen rendszert mutat be a 2. ábra: 1. Átfogó cél: a vízió; 2. Ágazati feladatok: specifikus ágazati célok; 3. Programok: az ágazati programok lebontását jelentô komplex intézkedéscsomagok; 4. Akciók: konkrét egyedi intézkedések. E fogalmak tehát a programhierarchia belsố rendjét tükrözik, és egyúttal megfeleltethetőek egy-egy szervezeti felelősségi körnek. Ezen a ponton válik a programköltségvetés pénzügyi technikából menedzsmenteszközzé.

\section{KONKLÚZIÓ}

Az önkormányzatok mai helyzetében különösen fontos, hogy erôforrásaikat, képességeiket koncentrálva vigyék sikerre a helyi közösségeket, bemutassák a szektor életképességét. Ehhez a szektornak ki kell emelkedni abból a depresszióból, kilátástalanságból, ahová sok önkormányzat süllyedt, és új eszközökre is szükségük lehet. Ilyen fontos eszköz lehet a tervezési rendszer átalakítása, modernizálása. A modernizálás jegyében különösen fontosnak tartjuk a stratégiaorientált tervezést, melyben kiemelt szerepet kap a teljesítménymenedzsment és a programköltségvetés.

A stratégiai tervezésen alapuló modern tervezô-elemzô módszerek önkormányzati alkalmazására szükség van önkormányzati mérettôl függetlenül, a konkrét módszerek kiválasztása és bevezetése során azonban szükség van a szegmentálásra. A szegmentálás a méret és a feladatellátás pénzügyi és vagyoni feltételeinek eltérései miatt fontos.

A programköltségvetés és a teljesítménymenedzsment sem az önkormányzati, sem az általában állami szférában, így a központi költségvetés vonatkozásában sem vált egyelőre meghatározóvá. Ennek látszólag törvényi okai vannak. A szabályozás például a közfeladatok ellátása vonatkozásában igyekszik minél szúkebb mozgásteret hagyni, mintegy atyáskodva az ellátók felett. Az érv nyilván a magyar állampolgárok egységes közszolgáltatásokhoz való joga. Ez ugyanakkor ellátásszervezési és pénzügyi vonatkozásban az ellátásért adott esetben felelôs önkormányzat számára csökkenti az alternatív megoldások keresésének lehetôségét. A törvényi kereteket részben tehát az uniós jogharmonizáció is módosítja, de elsôdlegesen a politikai akarattól függ. Sem a központi, sem az önkormányzati alrendszer vonatkozásában nem született meg olyan felismerés, hogy az intézményi ellátás szabadsága mellett a szervezeti, illetve mélyebb módszertani szabadság irányába el lehetne menni, mintegy nagykorúsítva a felelôs vezetôket. 
A közszektorban folyó innovációk, beleértve a tervezési rendszer megújítására vonatkozókat is, nagyfokú körültekintést és természetükból fakadóan jelentôs alsóbb szintû elôkészítést és munkát kívánnak, mielôtt sikeresen és teljes mértékben be lehetne ôket vezetni. Vajon a technikai feltételek vagy a vezetôk vonakodása rejti-e a nagyobb kihívást? Úgy gondoljuk, hogy a helyi vezetôk stratégiai szemlélete, elôrelátása, a saját és a helyi érdek felismerése, a település sikerre vitelének szándéka jelentheti a lehetôséget a továbbfejlesztés kihívásainak legyôzésében.

\section{JEGYZETEK}

1 A tanulmány a KÖFOP-2.1.2-VEKOP-16-2016-00001 „A jó kormányzást megalapozó közszolgálat-fejlesztés” címú projekt „Jövốorientált önkormányzatok modelljei” altéma keretében készült.

2 2011. évi CXCV. törvény az államháztartásról.

3 2011. évi XLXXXIX. törvény Magyarország helyi önkormányzatairól.

4 2011. évi CXCIV. törvény Magyarország gazdasági stabilitásáról.

5 Másrészt a tervezési tevékenység analitikus vizsgálata a tevékenység komplex jellegéből fakadóan nem függetleníthetố a többi vezetési alrendszertôl sem. A vezetési alrendszerekkel való kapcsolattal most nem foglalkozunk.

${ }^{6}$ Erről részletesen lásd OECD, 2017 tanulmányt, amelyet a magyar kormány rendelt meg a magyar közigazgatási reform értékelésérôl. Látható, hogy az eredményesség mérésének és a számszerú eredmények bemutatásának kultúrája egyelôre hiányzik Magyarországon; illetve Lentner, 2015.

7 A tervezés folyamatjellege mellett a tervezés rendszerszerú megközelítése is szükséges.

8 Ezek a technikák vagy megoldások a közszektor bármely szintjén alkalmazhatóak. A központi rendszerekben ugyanúgy, mint a dekoncentrált vagy decentralizált önkormányzati entitásokban. Egyszerú megoldásokról van szó, amelyek külön-külön is növelik a közszektor múködésének pénzügyi hatékonyságát. Összehangolt rendszerbe szervezve ugyanakkor hatásosságuk fokozott lehet. Erre teszünk kísérletet a jelen tanulmányban, ahogy néhány korábbiban is (pl. Kovács, 2015; 2016).

9 Az önkormányzatok állami finanszírozása a kísérletek és vágyak ellenére sem fedezheti a feladatellátás teljes költségét, ahogy ez nem is történik meg (vö. Vigvári, 2010; Kovács, 2012), ilyen módon a kormányzat által átvett feladatok esetében a kormányzatnak is el kellett vennie az önkormányzatok megosztott bevételeibốl (pl. szja, gépjármúadó) annak érdekében, hogy maga oldalán enyhítse a feladatellátás állami finanszírozásának veszteségét.

10 A számviteli törvényi keretekbôl való kilépésre mint szimbolikus aktusra gondoljunk, hiszen a törvényi megfelelés nem kerülhetố meg.

11 A közszektor számvitelével foglalkozó szakértôk, például Kassó Zsuzsa hosszú éveken keresztül küzdöttek az eredményszemléletû́ számvitel közszektorban való alkalmazásáért, de sikerük a mai napig csak részleges (Vigvári, 2011; Szappanos 2014). A Pénzügyi Szemle áttekintô oldalt is múködtet a kérdésről (lásd www. penzugyiszemle.hu/tanulmanyok-eloadasok/atteres-az-eredmenyszemleletu-szamvitelre-attekintes).

\section{FELHASZNÁLT IRODALOM}

Donath, Liliana - Milos, Marius (2008): Public Sector Efficiency According to COFOG Classification in the European Union. MPRA Papers, No. 12927, West University of Timisoara, Timisoara.

Döbrönte Katalin (2008): Beruházási szemlélet és fejlesztési szemlélet ütköztetése az önkormányzatok gyakorlatában. In: Önkormányzatok gazdálkodása - helyi fejlesztés. Tanulmánykötet, Pécsi Tudományegyetem Közgazdaságtudományi Kar, Pécs, 135-142.

Eurostat (2007): Manual on sources and methods for the compilation of COFOG Statistics. Classification of the Functions of Government (COFOG). Eurostat Methodologies and Working Papers, Eurostat, Luxembourg. 


\section{Polgári Szemle · 14. évfolyam 1-3. szám}

Faragó László (1997): Tervezéselméleti alapvetések. Tér és Társadalom, 11. évf., 3. sz., 1-15., https://doi. org/10.17649/TET.11.3.425.

Gazsó István - Kovács Róbert (2014): A pénzügyimodell-vizsgálatok bemutatása. Kutatási jelentés, Helyi Obszervatórium.

Gyôrffi Dezsố - Vigvári András (szerk.) (2009): A közpénzügyek nagy kézikönyve. Complex Kiadó, Budapest.

Hegedüs, József - Krajsóczky, Erzsébet - Rosenberg, Philip (1999): Program budgeting. Training Manual, Modernizing Financial Management for Hungarian Local Governments 1. The Urban Institute - USAID.

Johnsen, Age (2015): Strategic Management Thinking and Practice in the Public Sector. Financial Accountability and Management, Vol. 31, No. 3, https://doi.org/10.1111/faam.12056.

Kovács Róbert (2007): Az önkormányzatok költségvetési támogatásának reformja - modellkísérletek. Kutatási jelentés, Helyi Obszervatórium.

Kovács Róbert (2012): Az önkormányzatok adóssághelyzete. Helyi Obszervatórium, http://lrmi-cloud.hu/portal/ index.php/hu/publikaciok/71-kovacs-robert-az-onkormanyzatok-eladosodasarol-letoltheto-anyag.

Kovács Róbert (2015): A programköltségvetés. In: Benedek István - Kovács Róbert (szerk.): A teljesítményelvú önkormányzati menedzsment. TÖOSZ - Helyi Obszervatórium, http://lrmi-cloud.hu/portal/index. $\mathrm{php} / \mathrm{hu}$ /projektek/68-2013-14-mafis-teljesitmenyelvu-onkormanyzati-penzugyi-menedzsment.

Kovács Róbert (2016): A programköltségvetés és a teljesítményelvú, hatékony önkormányzati pénzügyi menedzsmentet támogató eszközök. In: Erdôs Katalin - Komlósi Éva (szerk.): Tanítványaimban élek tovább. Emlékkötet Buday-Sántha Attila tiszteletére. Pécsi Tudományegyetem Közgazdaságtudományi Kar, Pécs, 343-360., http://dportal.ktk.pte.hu/sites/default/files/hir_mellekletek/2017/04/e-book_tanitvanyaimban_elek_tovabb.pdf.

Kovács Róbert - Sükösd Anikó (2014): Az állami támogatáspolitika változása és hatása az önkormányzatok finanszírozási helyzetére. In: Önkormányzati pénzügyek vizsgálatát megalapozó háttértanulmányok. Helyi Obszervatórium, 47-62., http://lrmi-cloud.hu/portal/index.php/hu/publikaciok/74-kovacs-robert-sukosd-aniko-onkormanyzati-penzugyi-vizsgalatot-megalapozo-hattertanulmanyok-onkormanyzatokt.

László Csaba (1994): Tépett vitorlák. Az államháztartásról közigazgatási és jogi szempontból. Aula Kiadó, Budapest.

Lentner, Csaba (2015): Uncertainty Factors in National Economy Planning - International Effects and Hungary's Outlook Up to 2050. Central European Political Science Review, Vol. 16. No. 62, 9-26.

Magyary Zoltán (1923): A magyar állam költségvetési joga. Studium Kiadó, Budapest.

OECD (2017) Hungary: Public Administration and Public Service Development Strategy, 2014-2020. OECD, 13 December.

Poister, Theodore H. (2010): The Future of Strategic Planning in the Public Sector: Linking Strategic Management and Performance. Public Administrative Review, Vol. 70, No. 1, https://doi.org/10.1111/ j.1540-6210.2010.02284.x.

Rosenberg, Phil (1999): Program Budgeting, Modernizing Financial Management. The Urban Institute - Metropolitan Research Institute, Washington-Budapest.

Sisa Krisztina A. (2014): Települési önkormányzatok tervezési módszereinek továbbfejlesztése. Elmozdulás a stratégiaorientált menedzsmentszemlélet irányába. Doktori disszertáció, Kaposvári Egyetem, Kaposvár.

Sivák József - Vigvári András (2012): Rendhagyó bevezetés közpénzügyek tanulmányozásába. Complex Kiadó, Budapest.

Szappanos Júlia (2014): Áttérés az eredményszemléletú számvitelre - áttekintés. Pénzügyi Szemle Online, www. penzugyiszemle.hu/tanulmanyok-eloadasok/atteres-az-eredmenyszemleletu-szamvitelre-attekintes.

Vigvári András (2010): Is the Conflict Container Full? Problems of Fiscal Sustainability at the Local Government Level in Hungary. Acta Oeconomica, Vol. 60, No. 1, 49-77, https://doi.org/10.1556/aoecon.60.2010.1.4.

Vigvári András (2011): Bevezetés a közszektor kontrollingba. Szegedi Egyetem, http://rs1.sze.hu/ bedecsj/P\%E9nz\%FCgytan\%20II./gyakorlatok\%20anyagai/7.\%20het/kozkontrol2.pdf.

Wauders, Benedict (2017): Strategic Management in the Public Sector: a Tool for Improving Performance of Ongoing Operations or Redefining Performance to Meet New Challenges? Report to the European Commission's Public Administration and Governance Network. 